\title{
Marie-Antoinette sur le Net : de l'usage de la reine ou des usages d'une mémoire royale et féminine.
}

\section{Cécile Berly}

\section{(2) OpenEdition \\ 1 Journals}

\section{Édition électronique}

URL : https://journals.openedition.org/ahrf/849

DOI : 10.4000/ahrf.849

ISSN : 1952-403X

Éditeur :

Armand Colin, Société des études robespierristes

\section{Édition imprimée}

Date de publication : 1 septembre 2003

Pagination : 85-101

ISSN : 0003-4436

\section{Référence électronique}

Cécile Berly, «Marie-Antoinette sur le Net: de l'usage de la reine ou des usages d'une mémoire royale et féminine. ", Annales historiques de la Révolution française [En ligne], 333 | juillet-septembre 2003, mis en ligne le 20 avril 2004, consulté le 24 avril 2022. URL : http://journals.openedition.org/ahrf/849 ;

DOI : https://doi.org/10.4000/ahrf.849

Ce document a été généré automatiquement le 24 avril 2022.

Tous droits réservés 


\title{
Marie-Antoinette sur le Net : de l'usage de la reine ou des usages d'une mémoire royale et féminine.
}

\author{
Cécile Berly
}

\section{RÉSUMÉS}

Internet serait l'ultime support de la vulgarisation de l'Histoire: à la mémoire de MarieAntoinette, l'une des figures de proue de cette histoire dite "grand public », sont consacrées de nombreuses pages Web. Celui-ci transmet un savoir commun sur ce personnage royal et féminin et le réduit à une mémoire simple. Ce média électronique étaye l'étrange pérennité de cette mémoire mythique: partager sa passion pour cette Marie-Antoinette reine et belle et célébrer cette femme souffrante et guillotinée. Internet obéit à la loi biographique propre à ce personnage historique : superposer « deux » Marie-Antoinette, étrangères l'une à l'autre. Enfin, ce monde virtuel « cristallise » cette mémoire autour d'objets, de lieux ou d'individus; l'art et la légendaire douceur de vivre $\mathrm{du}$ règne de Marie-Antoinette permet une adroite politique commerciale de son nom et de sa mémoire.

Marie-Antoinette on the Net : How a Queen can be Put to Use and Serve both Royalty and Gender Internet seems to be the ultimate medium for vulgarizing history, judging by the number of websites devoted to the memory of Marie-Antoinette, a true figure-head of historical popularization. It conveys a common fund of knowledge on her royal and female status, oversimplifying the memory of her that remains and revealing the strange mythical staying-power of that memory : a celebratory passion widely shared for Marie-Antoinette the queen and rare beauty, the woman made to suffer and sent to the scaffold. Internet applies the biographical rule pertaining to this historical figure by superimposing "two" Marie-Antoinettes, the one alien to the other. Finally, 
this virtual world highlights objects, places and individuals that help "crystallize" that memory ; the art and legendary self-indulgence of Marie-Antoinette's reign give rise to an astute commercialization of her name and memory. 